\title{
Physicochemical Properties and Sensory Evaluation of Non-Meat Ingredients Chicken Sausage
}

\author{
M. Pagthinathan and A.P. A. S. Gunasekara
}

\section{ABSTRACT}

Non-meat ingredients are used to impart flavor, slow bacterial growth, and increase the yield of the sausage production. To study the quality of chicken sausage incorporated with non-meat ingredients namely, soy protein powder, non-fat milk powder and potato starch at the rate of $2 \%$ (w/w) concentration. Sausage samples were analyzed for physical, nutritional, and sensory properties during refrigerated storage at $-4{ }^{\circ} \mathrm{C}$. The nutritional, physical and sensory characteristics were analyzed, at day 1, week 1, week 2 and week 3 of storage. Moisture, ash, dry matter, fat, pH, texture, and color were significantly difference $(p<0.05)$ among the treatments at day one. During storage the ash, $\mathrm{pH}$ content and dry matter content were significantly $(p<0.05)$ increased, and fat content and moisture content was significantly $(p<0.05)$ decreased storage period. At week one, the higher hardness value showed in soy protein powder incorporated chicken sausage and least value showed in without added non-meat ingredient (control) sausage. As results of organoleptic characteristics revealed that, $2 \%$ of potato starch incorporated chicken sausage had the highest mean score of overall quality of all sensorial properties namely, color, taste, texture, flavor, and overall acceptability.

Keywords: Non-meat ingredients, Physical, Nutritional, Sausage, Sensory.

\section{INTRODUCTION}

Sausage is a food product resulting from the gathering of proper ingredient in the precise proportion coupled with a structured design and controlled process. Sausages are the best sources of minerals, vitamins and complete proteins which contains essential amino acids [1]. The chicken sausages are of perishable nature as high moisture content, minerals, and protein. As a result, it is increasing the microbial activity and loss in sensory attributes [2]. The criteria for the application of functional non-meat ingredients are improve of keeping quality, sensory quality of the products and safe for consumers [3].

Soy proteins affected texture properties differently, improve hardness, cohesiveness, and breaking strength of sausage [4]. Addition of soy protein was significantly reduced the cholesterol bacterial count in the sausage [3]. Incorporation of soy protein is considerably changed in physicochemical, microbiological, sensory and textural characteristics of low fat emulsion sausage.

Additions of dairy ingredients have been used as good binders in sausage to improve texture and sensory properties and reduce cooking loss [6]. Skim milk powder is widely used as neutral filler with good water binding effect in comminuted meat products, but lactose may cause discoloration of meat products because of maillard reactions with proteins [7]. Further it also reduced water holding capacity, while increased hardness and decreased springiness with the lowest mineral level in frankfurters sausage [8].
Published Online: January 9, 2021

ISSN: $2684-1827$

DOI: $10.24018 /$ ejfood.2021.3.1.196

\section{Pagthinathan *}

Senior Lecture in Animal Science, Faculty of Agriculture, Eastern University Sri Lanka, Sri Lanka. (e-mail: pagthymp@gmail.com) A.P. A. S. Gunasekara

*Corresponding Author

Various plant-derived polysaccharides are used in meat processing to bind water and change texture in low and reduced fat in sausage. Starches are multifunctional food ingredients. They have many functional applications, including gelling, adhesion, binding, emulsion stabilization, and moisture retention [9]. Starches could be used as "binders" to increase the emulsion characteristics of the sausage product. And also use of non-meat components such as starches can stimulate better-quality and healthier sausage [10]. Starches can act as "fillers" that bind water and fat by means of physical entrapment [11]. In sausage, potato starches are recommended to increase cooking yield or decrease loss from cooking, to improve texture and to extend shelf life [12]. Lipid oxidation effectively inhibited by the addition of starch.

Nonmeat ingredients add in food to achieve specific functions, for example, to aid in food processing, to increase the product's nutritive value like sausage to increase the product's palatability through regulating its physicochemical properties, and to extend the product's storage stability [13]. Therefore, the objective of our study was to assess the quality and shelf life of chicken sausage incorporated with of nonmeat ingredients concentrate with a level of $2 \%$.

\section{MAterials AND MethodS}

Chicken meat samples collected from the local meat shop. Other ingredients such as chicken, soy protein powder, nonfat milk powder and potato were purchased from supermarket. Also, artificial cellulose casing, spices, 
coconut oil, soy sauce and packing material were purchased from commercially.

\section{A. Source of Ingredients Used to Prepare Sausage}

Chicken, soy protein powder, nonfat milk powder and potato were purchased from commercially. Also, artificial cellulose casing, spices, coconut oil, soy sauce and packing material were purchased from commercially. Potato starch was prepared by slandered recommended method.

\section{B. Chicken Sausage Preparation}

Chicken meat was gutted, skinned, washed, and removed bones. Flesh and non-meat ingredients (Soy protein powder, nonfat milk powder and potato starch) were weighed. Chicken flesh was cut in small pieces and different ingredients used in preparing sausage samples. Chicken sausage samples were prepared according to the method described by [14]. Ingredients were blended to prepare sausage mixture, which was then stuffed into artificial cellulose casings, and then the casings were closed and tied off in desired sausage lengths [15]. The packed sausages were stored in a freezer at $-4{ }^{\circ} \mathrm{C}$ until the analyze. Each nonmeat ingredients such as Soy protein powder, nonfat milk powder and potato starch were separately added at $2 \%$ concentration as a treatment of the experiment. Sausage made without non-meat ingredients was used as control and in each treatment, three replicates were carried out.

\section{Nutritional Analysis of Sausages}

Sausages samples were analyzed to determine the chemical composition of sausages, such as dry matter, ash, and fat. The dry matter contents of sausages were determined by oven drying at $105^{\circ} \mathrm{C}$ to get constant weight as described by AOAC [15]. Ash content was determined by using muffle furnace at $550{ }^{\circ} \mathrm{C}$ for $4 \mathrm{hr}$ as mentioned in the method of AOAC [15]. Fat content was measured by the Soxhlet method with a solvent extraction system based on the method of AOAC [15]. pH of sausage samples was determinate by blending $5 \mathrm{~g}$ of sausage sample was blended with $5 \mathrm{~mL}$ of deionizer water as described by Hussein et al [17].

\section{Determination of Texture}

Texture was analyzed using food rheology tester (IMADA mode FRT series). Test results were drawn into a graph and its obtained using computer software attached to food rheology tester and the following parameters were recorded: Hardness, cohesiveness, springiness, gumminess, and chewiness were evaluated from the resulting force/deformation curve as described by (Briones-Labarca et al [18].

\section{E. Determination of Color}

The color parameters were measured using color analyzer probe. The color measurement was carried out using the Schubring [19]. $R$ value indicate the red, $G$ indicate the green value and $\mathrm{B}$ indicate the blue value. RGB converted to CIE L*a*b and HSV using RGB converter in the CIE indicate the International Commission on Illumination $\mathrm{L}^{*}$ indicates the intensity of light in black from 0 to 100 scales; $\mathrm{a}^{*}(+)$ red or (-) green and $\mathrm{b}^{*}(+)$ indicates yellow or (-) blue.

\section{F. Determination of Water Holding Capacity (WHC)}

Water holding capacity of sausage was determined by centrifugal method as described by Jauregui et al [20]. Around $2.5 \mathrm{~g}$ of each sausage sample was wrapped with filter paper (Whatman -3) and centrifuged at 3,000 rpm for $20 \mathrm{~min}$. Water holding capacity was calculated according to the described methods.

\section{G. Sensory Evaluation}

Sensory characteristics of sausages were evaluated for colour, flavour, texture, taste, and overall acceptability. This was conducted by 30 panelist, 9 points scale by Hedonic rating tests, ranging from excellent $($ score $=9)$ to very poor (score $=1$ ) as extremes, was used for evaluation. A questionnaire was used for the sensory assessment. Each panelist was asked to evaluate the samples from different treatment.

\section{H. Statistical Analysis}

All data were analyzed by using the Multivariate Analysis of Variance (MANOVA) and used to determine the significance level of the treatments, while the Duncan's Multiple range test (DMRT) was used for mean separation. The sensory analysis was carried out using Friedmans test for non-parametric data analysis.

\section{RESULTS AND DISCUSSIONS}

\section{A. Nutritional Attributes and pH of Sausage during Storage Period}

In Table I show that the dry matter content of the sausage ranged from $29.26 \pm 0.12 \%$ to $39.92 \pm 1.62 \%$. The highest mean value of dry matter content $(39.92 \pm 1.62 \%)$ of first week storage observed in potato starch added chicken sausage and lowest $(29.26 \pm 0.12 \%)$ mean value showed in without non-meat ingredient added sausage. At fourth week of storage, highest $(39.92 \pm 1.62 \%)$ mean value showed in potato starch added sausage and lowest (30.02 $\pm 0.12 \%)$ value was showed in control sausage. The dry matter content of sausage samples increased during storage period. There was significant difference $(\mathrm{p}<0.05)$ in dry matter content between treatments groups in four weeks of storage. The increase in dry matter content in the chicken sausage could be due to various non -meat ingredients used (soy protein powder, non-fat milk, and potato starch). Increase in dry matter content could be water vapor transmission of the packaging material [21].

Ash content is an indication of mineral element present in the sample. Ash content of non-meat ingredients added sausage it noticed that the ash content were significant $(\mathrm{p}<0.05)$ differences among all types of sausage (Table I). At first week of storage, the higher mean value of ash content $(3.00 \pm 3.00 \%)$ presented in potato starch and lowest mean value of ash content $(2.21 \pm 0.10 \%)$ observed in control sausage. By considering results at four weeks, the highest $(3.54 \pm 3.54 \%)$ mean value were showed in potato starch added sausage and also lowest $(2.51 \pm 0.06 \%)$ value in and control sausage. However, ash content could be increment correlated to the increment amount of dry matter (soy protein power, non-fat milk powder and potato starch) 
adding to sausage products and to the storage period [22]. According to results proved by this, there is a significant effect of different non-meat ingredients on ash content of sausage and all treatments showed slightly increased ash content along the storage period.

There was significant difference $(\mathrm{P}<0.05)$ in mean value of fat of sausage among the treatments in first week of storage. Moreover, at four weeks of storage, the highest mean value was recorded by soy protein added chicken sausage and lowest value in potato starch added chicken sausage.

There was significant difference $(\mathrm{P}<0.05)$ in $\mathrm{pH}$ between treatment groups in first week of storage. The $\mathrm{pH}$ of control sausage differed non-significantly $(\mathrm{P}<0.05)$, although it was slightly higher in sausages containing non-fat milk powder. It increased gradually with increase in storage period, which might be due to degradation of lactic acid and production of protein metabolites by bacteria [23]. The $\mathrm{pH}$ content at first week of storage, the highest mean value $(6.45 \pm 0.03)$ and lowest value $(6.28 \pm 0.03)$ of $\mathrm{pH}$ was showed in potato starch added chicken sausage and without non-meat ingredient added sausage, respectively. Similarly, at fourth week of storage, the highest mean value $(6.83 \pm 0.06)$ was recorded by potato starch added chicken sausage and lowest value $(6.50 \pm 0.05)$ non-meat ingredient added sausage.

\begin{tabular}{|c|c|c|c|c|c|}
\hline Trt & $1^{\text {st }}$ Day & $1^{\text {st }}$ Week & $2^{\text {nd }}$ Week & $3^{\text {rd }}$ Week & $4^{\text {th }}$ Week \\
\hline \multicolumn{6}{|c|}{ Dry matter (\%) Mean \pm SD } \\
\hline $\mathrm{T}_{1}$ & $35.54 \pm 0.34^{\text {def }}$ & $36.70 \pm 0.26^{\text {bcd }}$ & $36.31 \pm 1.09^{\text {cde }}$ & $35.67 \pm 0.34^{\mathrm{def}}$ & $36.93 \pm 0.85^{\mathrm{bc}}$ \\
\hline $\mathrm{T}_{2}$ & $34.55 \pm 0.15^{\mathrm{fg}}$ & $35.61 \pm 0.06^{\mathrm{def}}$ & $34.35 \pm 0.83^{\mathrm{g}}$ & $35.30 \pm 0.29^{\mathrm{efg}}$ & $36.31 \pm 0.14^{\text {cde }}$ \\
\hline $\mathrm{T}_{3}$ & $36.67 \pm 0.17^{\text {bcd }}$ & $37.83 \pm 0.03^{\mathrm{b}}$ & $36.64 \pm 0.40^{\text {bcd }}$ & $37.71 \pm 0.49^{b}$ & $39.92 \pm 1.62^{\mathrm{a}}$ \\
\hline $\mathrm{T}_{4}$ & $29.26 \pm 0.12^{\mathrm{j}}$ & $31.51 \pm 1.46^{\mathrm{h}}$ & $30.11 \pm 0.11^{\mathrm{ij}}$ & $30.91 \pm 0.66^{\mathrm{hi}}$ & $30.02 \pm 0.12^{\mathrm{ij}}$ \\
\hline \multicolumn{6}{|c|}{ Ash $(\%)$ Mean \pm SD } \\
\hline $\mathrm{T}_{1}$ & $2.28 \pm 0.06^{\mathrm{ij}}$ & $2.21 \pm 0.09^{j}$ & $2.41 \pm 0.02^{\mathrm{hi}}$ & $2.49 \pm 0.02^{\mathrm{gh}}$ & $2.51 \pm 0.02^{\mathrm{gh}}$ \\
\hline $\mathrm{T}_{2}$ & $2.66 \pm 0.10^{\mathrm{fg}}$ & $2.56 \pm 0.04^{\mathrm{fgh}}$ & $2.64 \pm 0.02^{\mathrm{fg}}$ & $2.72 \pm 0.20^{\mathrm{ef}}$ & $2.84 \pm 0.05^{\mathrm{e}}$ \\
\hline $\mathrm{T}_{3}$ & $3.00 \pm 3.00^{\mathrm{d}}$ & $3.25 \pm 3.25^{\mathrm{c}}$ & $3.33 \pm 3.33^{\mathrm{bc}}$ & $3.46 \pm 3.46^{\mathrm{ab}}$ & $3.54 \pm 3.54^{\mathrm{a}}$ \\
\hline $\mathrm{T}_{4}$ & $2.21 \pm 0.10^{\mathrm{j}}$ & $2.28 \pm 0.07^{\mathrm{ij}}$ & $2.30 \pm 0.08^{\mathrm{ij}}$ & $2.40 \pm 0.01^{\mathrm{hi}}$ & $2.51 \pm 0.06^{\mathrm{gh}}$ \\
\hline \multicolumn{6}{|c|}{ Fat $(\%)$ Mean \pm SD } \\
\hline $\mathrm{T}_{1}$ & $15.47 \pm 0.29^{\mathrm{a}}$ & $14.50 \pm 0.10^{\mathrm{b}}$ & $14.00 \pm 0.46^{\mathrm{c}}$ & $13.91 \pm 0.11^{\mathrm{c}}$ & $13.17 \pm 0.21^{\mathrm{def}}$ \\
\hline $\mathrm{T}_{2}$ & $12.83 \pm 0.10^{\mathrm{cd}}$ & $12.83 \pm 0.31^{\mathrm{efg}}$ & $12.47 \pm 0.06^{\mathrm{gh}}$ & $11.27 \pm 0.57^{\mathrm{k}}$ & $11.20 \pm 0.30^{\mathrm{k}}$ \\
\hline $\mathrm{T}_{3}$ & $13.53 \pm 0.15^{\mathrm{cd}}$ & $13.17 \pm 0.25^{\mathrm{def}}$ & $12.67 \pm 0.12^{\mathrm{fgh}}$ & $11.40 \pm 0.20^{\mathrm{jk}}$ & $11.03 \pm 0.21^{\mathrm{k}}$ \\
\hline $\mathrm{T}_{4}$ & $14.73 \pm 0.21^{\mathrm{b}}$ & $13.24 \pm 0.57^{\mathrm{de}}$ & $\begin{array}{l}12.26 \pm 0.29^{\mathrm{hi}} \\
\text { pH }\end{array}$ & $11.84 \pm 0.21^{\mathrm{ij}}$ & $11.13 \pm 0.21^{\mathrm{k}}$ \\
\hline $\mathrm{T}_{1}$ & $2.28 \pm 0.06^{\mathrm{ij}}$ & $2.21 \pm 0.09^{\mathrm{j}}$ & $2.41 \pm 0.02^{\mathrm{hi}}$ & $2.49 \pm 0.02^{\mathrm{gh}}$ & $2.51 \pm 0.02^{\mathrm{gh}}$ \\
\hline $\mathrm{T}_{2}$ & $2.66 \pm 0.10^{\mathrm{fg}}$ & $2.56 \pm 0.04^{\mathrm{fgh}}$ & $2.64 \pm 0.02^{\mathrm{fg}}$ & $2.72 \pm 0.20^{\mathrm{ef}}$ & $2.84 \pm 0.05^{\mathrm{e}}$ \\
\hline $\mathrm{T}_{3}$ & $3.00 \pm 3.00^{\mathrm{d}}$ & $3.25 \pm 3.25^{\mathrm{c}}$ & $3.33 \pm 3.33^{b c}$ & $3.46 \pm 3.46^{\mathrm{ab}}$ & $3.54 \pm 3.54^{\mathrm{a}}$ \\
\hline $\mathrm{T}_{4}$ & $2.21 \pm 0.10^{\mathrm{j}}$ & $2.28 \pm 0.07^{\mathrm{ij}}$ & $2.30 \pm 0.08^{\mathrm{ij}}$ & $2.40 \pm 0.01^{\mathrm{hi}}$ & $2.51 \pm 0.06^{\mathrm{gh}}$ \\
\hline
\end{tabular}

Treatment, $\mathrm{T}_{1}=$ soy protein added, $\mathrm{T}_{2}=$ non-fat milk added, $\mathrm{T}_{3}=$ potato starch added, $\mathrm{T}_{4}=$ without non-meat ingredients added. The Values are means of triplicates \pm standard deviation. Mean with the same letters are not significantly different at $(\mathrm{p}<0.05)$.

\section{B. Color of Sausages}

\section{a. RGB value}

There was significant difference $(\mathrm{p}<0.05)$ in $\mathrm{R}$ value between treatments. The highest $\mathrm{R}$ value was observed in non-fat milk powder added chicken sausage was reported lowest $\mathrm{R}$ value was observed in potato starch added chicken sausage. This value was indicated in Table II There was significant difference $(\mathrm{p}<0.05)$ in $\mathrm{G}$ value between treatments. Potato starch added chicken sausage and without non-meat ingredient added sausage was reported greatest $G$ value in sausage samples. There was significant difference $(p<0.05)$ in B value between sausage samples. In this study, high $\mathrm{B}$ value was observed in Potato starch added chicken sausage and lowest B value was observed in soy protein powder added chicken sausage.

\section{b. HSV Value}

Potato starch added chicken sausage was exhibit the highest $\mathrm{H}$ and $\mathrm{V}$ value and soy protein powder added chicken sausage was exhibit the highest $\mathrm{S}$ value.

\section{c. CIE $L^{*} a * b$ Value}

$\mathrm{L}$ value was high in without non-meat ingredient added sausage and value was low in soy protein powder added chicken sausage. $a^{*}$ value was high in soy protein powder added chicken sausage and a value was low in potato starch added chicken sausage. $a^{*}$ value of the sausage samples was show positive correlations except potato starch added chicken sausage. Potato starch added chicken sausage was show negative correlations $(-2.09 \pm 0.86)$.

Reddest sausage was soy protein powder added chicken sausage and non-fat milk powder added chicken sausage were light brown color. Potato starch added chicken sausage showed greenish brown color correlations. $b$ value was high in soy protein powder added chicken sausage and $b$ value was low in potato starch added chicken sausage. All the sausage samples show positive relations. This study result show similar findings with Piotrowiez and Mellado [24]. Bourke and Walder [25] reported the color changes showed an increase in $\mathrm{L}$ while the $\mathrm{a}^{*}$ values decreased in relative to $b^{*}$ values conforming that a brown fermented fish mince sausage was produced.

TABLE II: COLOR CHANGE IN THE SAUSAGE

\begin{tabular}{|c|c|c|c|}
\hline Trt & RGB value & HSV value & CIE L*a*b value \\
\hline \multirow[t]{3}{*}{$\mathrm{T}_{1}$} & $\mathrm{R} 235 \pm 1.41^{\mathrm{a}}$ & $\mathrm{H} 15.38 \pm 0.64^{\mathrm{c}}$ & $\mathrm{L} 54.89 \pm 0.54^{\mathrm{b}}$ \\
\hline & G $75.5 \pm 2.12^{c}$ & S $91.28 \pm 0.35^{\mathrm{a}}$ & A $59.37 \pm 0.36^{\mathrm{a}}$ \\
\hline & B $20.5 \pm 0.71^{\mathrm{d}}$ & $\mathrm{V} 92.16 \pm 0.56^{\mathrm{a}}$ & B $60.86 \pm 0.71^{\mathrm{a}}$ \\
\hline \multirow[t]{3}{*}{$\mathrm{T}_{2}$} & R $244 \pm 2.83^{\mathrm{a}}$ & $\mathrm{H} 13.93 \pm 2.11^{\mathrm{c}}$ & $\mathrm{L} 62.46 \pm 0.93^{\mathrm{a}}$ \\
\hline & G $109 \pm 4.24^{b}$ & $\mathrm{~S} 71.34 \pm 3.73^{\mathrm{b}}$ & A $48.78 \pm 0.49^{b}$ \\
\hline & B $70 \pm 9.90^{\mathrm{c}}$ & $\mathrm{V} 95.69 \pm 1.11^{\mathrm{a}}$ & B $46.70 \pm 3.93^{b}$ \\
\hline \multirow[t]{3}{*}{$\mathrm{T}_{3}$} & R $163 \pm 1.41^{\mathrm{c}}$ & $\mathrm{H} 46.79 \pm 2.09^{\mathrm{a}}$ & $\mathrm{L} 63.06 \pm 0.08^{\mathrm{a}}$ \\
\hline & $\mathrm{G} 152.5 \pm 0.71^{\mathrm{a}}$ & S $29.14 \pm 1.05^{d}$ & $A-2.09 \pm 0.86^{\mathrm{d}}$ \\
\hline & B $115.5 \pm 0.71^{\mathrm{a}}$ & V $63.92 \pm 0.55^{\mathrm{b}}$ & B $20.89 \pm 0.30^{\mathrm{d}}$ \\
\hline \multirow[t]{3}{*}{$\mathrm{T}_{4}$} & R $184.00 \pm 7.07^{b}$ & $\mathrm{H} 38.77 \pm 0.13^{\mathrm{b}}$ & $\mathrm{L} 64.67 \pm 2.44^{\mathrm{a}}$ \\
\hline & $\mathrm{G} 152.50 \pm 0.71^{\mathrm{a}}$ & $\mathrm{S} 44.85 \pm 6.10^{\mathrm{c}}$ & A $4.21 \pm 0.06^{c}$ \\
\hline & B $95.00 \pm 5.66^{\mathrm{b}}$ & $\mathrm{V} 63.34 \pm 9.71^{\mathrm{b}}$ & B $34.50 \pm 0.23^{c}$ \\
\hline
\end{tabular}




\section{Texture Profile}

The texture profile was $(\mathrm{p}<0.05)$ found among the samples for all parameters Table III. Texture profiles are affected by many processing factors such as the type and amount of ingredients, additives, heat treatment and equipment used.

TABLE III: CHANGES IN TEXTURE

\begin{tabular}{cccccc}
\hline Trt & $\begin{array}{c}\text { Hardness } \\
(\mathrm{N})\end{array}$ & Springiness & Cohesiveness & $\begin{array}{c}\text { Gumminess } \\
(\mathrm{N})\end{array}$ & $\begin{array}{c}\text { Chewiness } \\
(\mathrm{N})\end{array}$ \\
\hline $\mathrm{T}_{1}$ & $4.8 \pm 0.3^{\mathrm{a}}$ & $0.25 \pm 0.03^{\mathrm{b}}$ & $0.45 \pm 0.02^{\mathrm{c}}$ & $1.51 \pm 1.24^{\mathrm{b}}$ & $0.55 \pm 0.06^{\mathrm{c}}$ \\
$\mathrm{T}_{2}$ & $4.25 \pm 0.025^{\mathrm{b}}$ & $0.23 \pm 0.025^{\mathrm{b}}$ & $0.35 \pm 0.010^{\mathrm{d}}$ & $2.42 \pm 1.582^{\mathrm{b}}$ & $0.43 \pm 0.117^{\mathrm{c}}$ \\
$\mathrm{T}_{3}$ & $3.17 \pm 0.06^{\mathrm{d}}$ & $0.38 \pm 0.02^{\mathrm{a}}$ & $1.60 \pm 0.10^{\mathrm{a}}$ & $5.07 \pm 0.40^{\mathrm{a}}$ & $1.90 \pm 0.14^{\mathrm{a}}$ \\
$\mathrm{T}_{4}$ & $3.7 \pm 0.10^{\mathrm{c}}$ & $0.34 \pm 0.03^{\mathrm{a}}$ & $0.66 \pm 0.02^{\mathrm{b}}$ & $2.44 \pm 0.12^{\mathrm{b}}$ & $0.83 \pm 0.02^{\mathrm{b}}$ \\
\hline \multicolumn{7}{c}{ Treatment, $\mathrm{T}_{1}=$ soy protein added, $\mathrm{T}_{2}=$ non-fat milk added, $\mathrm{T}_{3}=$ potato } \\
\\
starch added, $\mathrm{T}_{4}=$ without non-meat ingredients added. The Values are \\
means of triplicates \pm standard deviation. Mean with the same letters are \\
not significantly different at (p<0.05).
\end{tabular}

The highest mean value of hardness $(4.8 \pm 0.3 \mathrm{~N})$ observed in soy protein added sausage and lowest mean value $(3.7 \pm 0.10 \mathrm{~N})$ showed in without non-meat ingredient added sausage. Huda et al [26] reported hardness could be correlated the moisture content. Non-meat ingredients (soy protein powder, non-fat milk powder and potato starch) could add also influence hardness of the sausage [26]. Who reported the hardness of sausages increased when the starch level was increased. Similar result was reported by Mohamed et al [27]. In this study hardness of all non-meat sausage in favorable hardness was higher than chicken sausage it would be adding of soy protein, non-fat milk and potato starch.

There was significant difference $(\mathrm{P}<0.05)$ in springiness of sausage between groups. Similar result was reported by Huda et al [26] agree with these results. Springiness represents the extent of recovery of sausage height and sometimes referred to as "elasticity".

In this study, springiness of sausages presence of favorable condition might be due to freshness of ingredients. The result showed that the cohesiveness of sausages was in favorable range (0.28-0.42) according to Huda et al [26].

The differences could be due to the ingredients used for example non-meat ingredients significantly improved meat product cohesiveness [28]. Who reported Sarcoplasmic proteins greatly affected the cohesiveness. In this study all treatments showed a different sarcoplasmic proteins solubility (soyproteinadded- $0.45 \pm 0.02$, non-fat milk added $0.35 \pm 0.010$, potato starch added $-1.60 \pm 0.10$ and control $0.66 \pm 0.02)$. Li et al. [29] reported chicken has ability to retain water and therefore would reduce the hardness, springiness, and cohesiveness of the chicken sausage. Gumminess There was significant difference $(p<0.05)$ between sausages groups. There was significant difference $(\mathrm{p}<0.05)$ between sausage groups. Chicken sausage and result was in favorable range (3.5-8.6) according to findings of Dincer and Cakli [30]. Pietrasik [31] reported protein content was the variable that most influences chewiness, along with the other characteristics such as hardness, gumminess, protein, and fat also affected the chewiness, with a reduction in fat resulting in an increase in chewiness value. The secondary parameters of gumminess and chewiness behaved similarly to the parameters on which they are dependent which is hardness [32].

\section{Water Holding Capacity of Sausages}

The water-holding capacity is a vital component for the quality of meat. In the present study water holding capacity of sausages was $(\mathrm{p}<0.05)$ varied among four types of sausages. According to this study the decreasing trend of water holding capacity was observed during storage period in the all the samples. On the other hand, potato starch added sausage shown lower retention of water compare to other non-meat ingredient sausage. It is due to when the $\mathrm{pH}$ decline in the sausages dehydration was taken place as a result decrease in water retention capacity which is, consequently, the reduction in water activity in sausages [33].

\section{E. Sensory Evaluation}

Sensory evaluation performed through a panel of 30 untrained judges. The experimental sausage samples coded with numbers for each treatment. Panelists marked the score for each attribute of a sample separately. Water was provided for mouth washing between samples.

A nine (9) point hedonic scale ranking method used for this analysis. Sensory evaluation of sausage made by incorporating different non-meat ingredients of at $2 \%$ concentration, revealed that, there was the sensory scores of the different non-meat ingredients added chicken sausages at are indicated in Fig. 1, the results revealed that, there were significant $(\mathrm{p}<0.05)$ differences among the different treatments on the sensory attributes namely, color, taste, texture, flavor, and overall acceptability. Higher score obtained in potato starch added sausage next to soy protein added sausage and least score observed in without non-meat indigent added sausage. Taste is the primary factor, which determines the acceptability of any product, which has the highest impact on success of product [34]. The nonmeat ingredient incorporated with sausage had the highest score overall acceptability characteristics based on the organoleptic point of view compared to without non-meat indigent added sausage. From the overall acceptability scores, the potato starch added sausage had the highest score, mean value 7.6 in a nine point hedonic scale. In general, potato starch added sausage showed the higher score in taste, flavor, and overall acceptability. According to the result, most of the panelist were preferred potato starch added sausage.

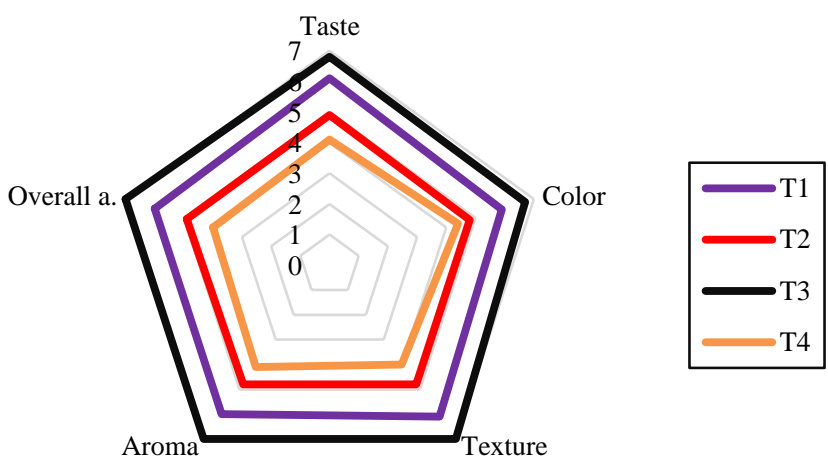

Fig 1: variation of sensory attributes at two weeks of storage $\mathrm{T}_{1}=$ soy protein added, $\mathrm{T}_{2}=$ non-fat milk added, $\mathrm{T}_{3}=$ potato starch added, $\mathrm{T}_{4}=$ control. 


\section{CONCLUSION}

Ash, pH, and dry matter increased all the sausage samples during the experimental period whereas fat content of all sausage samples decreased during the experimental period. Non-fat milk powder incorporated chicken sausage had lower fat content than other sausages. Soy protein incorporated chicken sausage had higher hardness value than without added non-meat ingredients incorporated chicken sausage. Potato starch incorporated chicken sausage was preferable by most of the panelist.

\section{ACKNOWLEDGMENT}

The author is grateful to Eastern University, Sri Lanka, Sri Lanka for financial assistant to the research work.

\section{REFERENCES}

[1] Verbeke W., Perez- Cueto F.J.A., de Barcellos M.D., Krystallis A. and Grunert. K.G. (2010). European citizen and consumer attitudes and preferences regarding beef and fork. Meat Science, 84: 284-292.

[2] Kumar, D and Tanwar, V.K. (2011) Effects of incorporation of ground mustard on quality attributes of chicken nuggets. Journal of food science and technology. 1;48(6):759-762.

[3] Yadaw, S., Tanwar, V., Sharma, J. and Yadav, S. (2013). Effect of added soy protein on physico- chemical properties of chevon patties. Journal of Meat Science and Technology, 1(1): 35-39.

[4] Feng, J., Xiong, Y.L. and Mikel, W.B. (2003). Textural properties of pork frankfurters containing thermally/enzymatically modified soy proteins. Journal of Food Science, 68(4), pp.1220-1224.

[5] Feng, J., Xiong, Y. and Mickel. (2002). Textural properties of pork frankfurters containing thermally/ enymatically modified soy proteins. Journal of Food Science, (1):1220-1224.

[6] Hung, S.C. and Zayas, J.F. (1992). Functionality of milk proteins and corn germ protein flour in comminuted meat products 1 . Journal of Food Quality, 15(2), pp.139-152.

[7] Ellekjær, M.R., Næs, T. and Baardseth, P., 1996. Milk proteins affect yield and sensory quality of cooked sausages. Journal of food science, 61(3), pp.660-666.

[8] Hayes, J., Desmond, E., Trory, D., Buckle, D. and Mehr. (2005). The effect of whey protein- enriched fractions on the physical and sensory properties of frankfurters. Meat Science, 71: 238-243.

[9] Pietrasik, Z. (1999). Effect of content of protein, fat and modified starch on binding textural characteristics, and colour of comminuted scalded sausages. Meat Science, 51(1),17-25.

[10] Baranowska, H. M. (2004). Starch as a Functional Addition in Meat Batters. Nova Science Publishers, Inc., New York, 115-123.

[11] Heinz, G. and Hautzinger, P. (2009). Meat processing technology for small to medium scale producers. FAO.

[12] Muthia, D., Nurul, H. and Noryati, I., 2010. The effects of tapioca, wheat, sago and potato flours on the physicochemical and sensory properties of duck sausage. International Food Research Journal, 17(4).

[13] Das, A.K., Anjaneyulu, A.S.R., Verma, A.K. and Kondaiah, N. (2008). Physicochemical, textural, sensory characteristics and storage stability of goat meat patties extended with full-fat soy paste and soy granules. International journal of food science \& technology, 43(3), 383-392.

[14] Pagthinathan, M. and Nafees, M.S.M. (2018). Physicochemical Properties and Sensory Evaluation of Fermented Sausage using Probiotic Bifidobacterium. Physicochemical Properties and Sensory Evaluation of Fermented Sausage using Probiotic Bifidobacterium, International Journal of Research Publications12(1), 01-08.

[15] Yadav, S., Pathera, A.K., Islam, R.U., Malik, A.K. and Sharma, D.P (2018). Effect of wheat bran and dried carrot pomace addition on quality characteristics of chicken sausage. Asian-Australasian journal of animal sciences, 31(5), .729.

[16] AOAC. (2005). Official methods of analysis of Anaysis.18th Ed. Association of Official Analytical Chemists. Gaithersburg, Maryland, USA.
[17] Hussein, F.H., Seyed Hadi Razavi, S.H. and Emam-Djomeh, Z. (2017). Physicochemical Properties and Sensory Evaluation of Reduced Fat Fermented Functional Beef Sausage. Applied food biotechnology, 4 (2):93-102.

[18] Briones-Labarca, V., Perez-Won, M., Zamarca, M., Aguilera-Radic, J.M. and Tabilo-Munizaga, G. (2012). Effects of high hydrostatic pressure on microstructure, texture, colour and biochemical changes of red abalone (Haliotis rufecens) during cold storage time. Innovative Food Science \& Emerging Technologies, 13, 42-50.

[19] Schubring, R. (2003). Colour measurement for the determination of the freshness of fish. Quality of fish from catch to consumer: Labelling, monitoring and traceability, pp.251-263.

[20] Jauregui, C. A., Regenstein, J. M. and Baker, R. C. (1981). A simple centrifugal method for measuring expressible moisture, a waterbinding property of muscle foods. Journal of Food Science, 46:1271- 1273 .

[21] Ahmad, S., Rizawi, J.A., Khan, M.S. and Srivastava, P.K. (2012). Effect of byproduct incorporation on physicochemical and microbiological quality and shelf life of buffalo meat fermented sausage. Journal of Food Processing Technology,3:(195):1-6.

[22] Ahmed, E.O. and Elhaj, G.A. (2011). The chemical composition microbiological detection and sensory evaluation of fresh fish sausage made from Clarias lazera and Tetradon fahaka. Journal of Fisheries and Aquaculture, 2(1), 11-16.

[23] Hugas, M., 1998. Bacteriocinogenic lactic acid bacteria for the biopreservation of meat and meat products. Meat Science, 49 , 139-150.

[24] Piotrowicz, I.B.B. and Mellado, M.M.S. (2015). Chemical, technological and nutritional quality of sausage processed with surimi. International Food Research Journal, 22(5), 2103.

[25] Bourke, F.J. and Walder, H., Immunolight LLC, 2012. Color enhancement utilizing up converters and down converters. U.S. Patent Application 13/204,355.

[26] Huda, N., Wei, L. Alistair, T., Ariffin, F. and Ismail, N. (2009). Quality characteristics of chicken sausages marketed in Malaysia. 11th ASEAN Food Conference.

[27] Ahamed, M. E. (2007). Effect of different binders on the quality of enrobed buffalo meat cutlets and theirs shelf life at refrigeration storage $\left(4 \pm 1^{\circ} \mathrm{C}\right)$. Meat Science, $75: 451-459$.

[28] Hsu, S.Y. and Chung, H.Y. (2001). Effects of $\kappa$-carrageenan, salt, phosphates and fat on qualities of low fat emulsified meatballs. Journal of Food Engineering, 47(2), 115-121.

[29] Li, R., Carpenter, J.A. and Cheney, R., 1998. Sensory and instrumental properties of smoked sausage made with mechanically separated poultry (MSP) meat and wheat protein. Journal of Food Science, 63(5), pp.923-929.

[30] Dincer, M.T. and Çakli, Ş. (2015). Textural acceptability of prepared fish sausages by controlling textural indicators. Turkish Journal of Veterinary and Animal Sciences, 39(3), 364-368.

[31]] Pietrasik, Z. (1999). Effect of content of protein, fat and modified starch on binding textural characteristics, and colour of comminuted scalded sausages. Meat Science, 51(1), 17-25.

[32] Cáceres, E., García, M.L. and Selgas, M.D. (2008). Effect of preemulsified fish oil-as source of PUFA $n-3$-on microstructure and sensory properties of mortadella, a Spanish bologna-type sausage. Meat Science, 80(2),183-193.

[33] Ruiz, J. N., Villanueva, N. D. M., Favaro-Trindade, C. S., and Contreras-Castillo, C. J. (2014). Physicochemical, microbiological and sensory assessments of Italian salami sausages with probiotic potential. Scientia Agricola, 71(3): 204-211.

[34] FAO. 2009. The State of Food and Agriculture. Available from fao.org/docre/012/i0680f/ i0680. Accessed 14 Aout 2016.

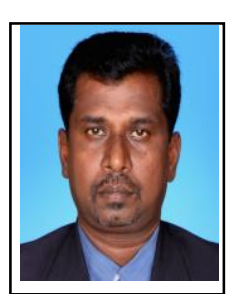

Dr. Mylvaganam Pagthinathan a Senior Lecturer in Department of Animal Science, Faculty of Agriculture, Eastern University, Sri Lanka. Dr. Mylvaganam Pagthinathan was basically graduate from Bachelor of Veterinary Science and animal Science and did the PhD in Dairy Technology in Malaysia. He is engaged in teaching and research work in the same department and has published national and international journals, he is supervising undergraduate and postgraduate students in the field of Dairy technology and Animal reproductive physiology.

Ms. A.P. A. S. Gunasekara. is a junior researcher and she is working with me in the Department at Eastern University, Sri Lanka. She is graduated in the same institute in 2019 and joined the department as a junior researcher. 